\title{
Toppling Slope Failure — Predicted Versus Actual, Ok Tedi, Papua New Guinea
}

\author{
N.R.P. Baczynski Ok Tedi Mining Ltd, Papua New Guinea \\ I.K. Sheppard Ok Tedi Mining Ltd, Papua New Guinea \\ K.J. Smith Ok Tedi Mining Ltd, Papua New Guinea \\ P. Simbina Ok Tedi Mining Ltd, Papua New Guinea \\ R. Sakail Ok Tedi Mining Ltd, Papua New Guinea
}

\begin{abstract}
This paper describes a classic toppling failure that has moved eight metres whilst retaining overall slope integrity. The failure is in the current Ok Tedi Mine open pit which is 3000 by $2000 \mathrm{~m}$ in plan and $700 \mathrm{~m}$ deep; final depth will be $1000 \mathrm{~m}$; although the final depth beneath the failure will be increased by only $30 \mathrm{~m}$. Large fault-defined block toppling failure was anticipated for some slope areas on the basis of kinematic stability analyses, and FLAC and UDEC numerical modelling undertaken during the 1997-2000 Risk-Based Slope Design Optimization Study. Signs of toppling instability were first noted in 2005. Ground displacements accelerated rapidly in 2006 during mining at the slope toe. Additional UDEC modelling predicted cyclic, stop-start type, cumulative displacements of 10-11 $\mathrm{m}$ as successive benches were mined down; with the slope face ravelling but the overall slope remaining stable. Actual slope behaviour and failure mode have largely mirrored modelling predictions. Spasms of ground displacement have been triggered by mining activity and, in some instances, compounded by intense rainfall and major pit blasting events. Further movement is expected as the slope is mined down to its final design depth.
\end{abstract}

\section{Introduction}

Ok Tedi is a major open pit copper-gold mine in the southern highlands near the western border of Papua New Guinea (PNG) and Indonesian Papua. Figure 1 is a photo of the mine pit and toppling failure area.

Mining commenced in 1982 and mining in the current pit life is scheduled to cease in 2013; although opportunities for extending the mine life are being actively investigated. About $150,000-200,000 \mathrm{t}$ of rock is mined daily; half this tonnage is ore. The current pit is approximately 3000 by $2000 \mathrm{~m}$ in plan and $700 \mathrm{~m}$ deep; final depth will be $1000 \mathrm{~m}$. Crest of the highest slope (i.e. West Wall) is at elevation of about RL $2100 \mathrm{~m}$. Overall slopes are $45^{\circ}$ but shallower slopes are mined in thrust-faulted ground.

Adverse weather conditions persist for much of the year. Clouds shroud the pit workings and annual rainfall is often $8-10 \mathrm{~m}$ but has exceeded $11 \mathrm{~m}$ in recent years. PNG is seismically active but conditions are moderate at the mine. Recent activity included magnitude 5.3 and 5.8 earthquakes (Richter scale) centred about $50 \mathrm{~km}$ from the mine (August 2007). Early downhole hydro-fracture tests indicated hydrostatic in situ stresses, but recent acoustic emission (AE) tests on cores suggest that horizontal stresses below current pit depth may be two to three times overburden stress.

Intact rock uniaxial compressive strengths vary from less than one MPa for clay-altered monzonite to more than $250 \mathrm{MPa}$ for massive siliceous siltstone; typical rock strengths are 40-120 MPa.

\section{Mine geology}

Figure 2 shows the pit layout and geology in plan. Figure 3 presents the $423100 \mathrm{~N}$ east-west geological section (looking north). 
Geology comprises a marine sedimentary sequence that was uplifted, faulted and folded during the regional orogeny of the New Guinea Highlands. During this orogeny, the sediments underwent thrust faulting and emplacement of granitic intrusions.

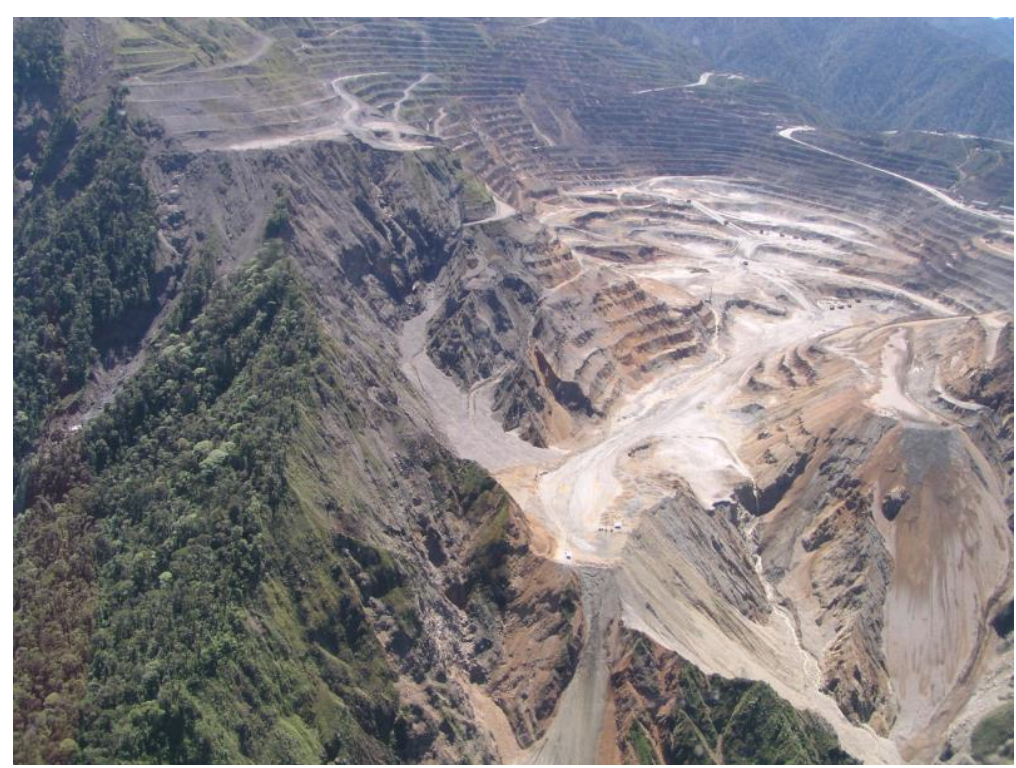

Figure 1 Ok Tedi pit looking north (toppling failure of 'bullnose' in centre of photo on West Wall)

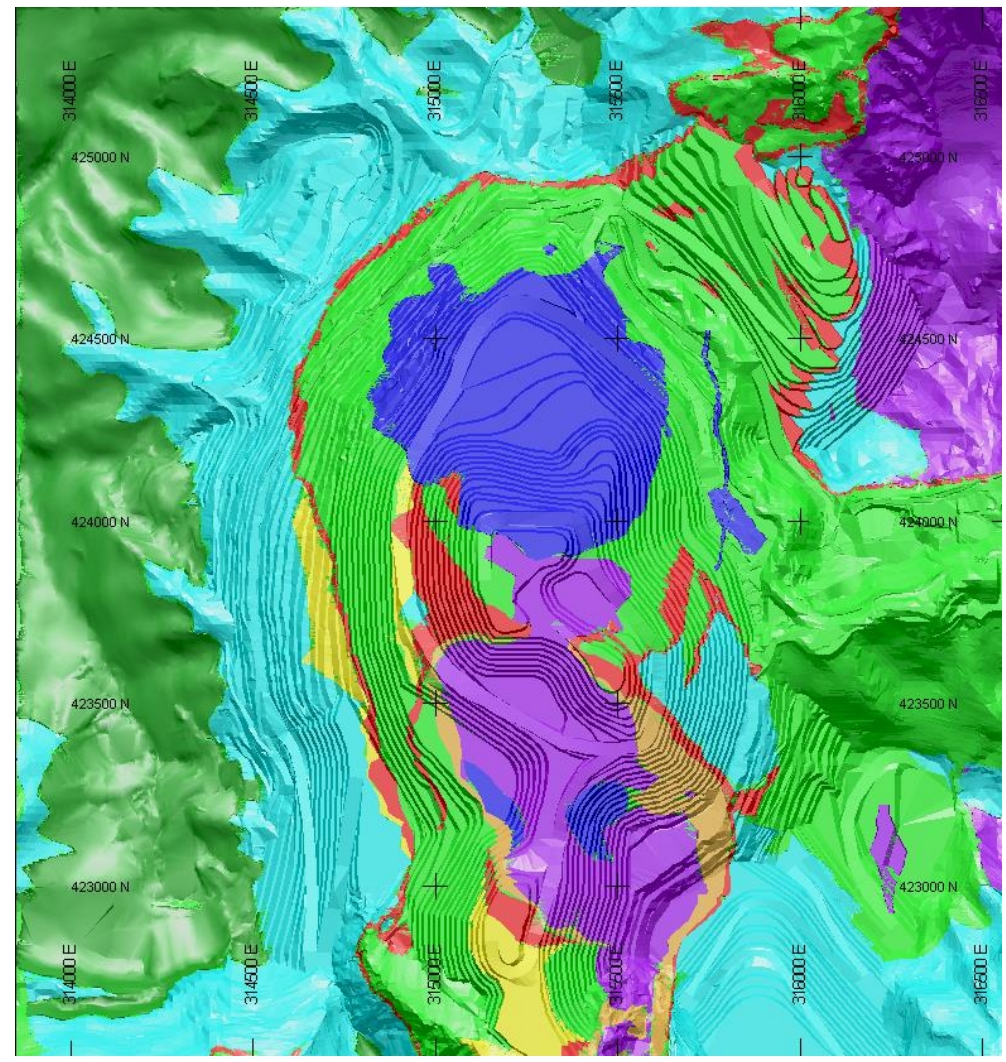

Fubilan Monzonite Porphyry (dark blue); Sydney Monzodiorite (purple); Southern Porphyry (blue within/near purple); Ieru Siltstone (bright green); Darai Limestone (pale blue); Pnyang Siltstone (dull olive green); Deep Skarn/Gold Coast Skarn (red); Endoskarn (orange); Taranaki/Parrot's Beak Thrusts (yellow); Taranaki/Parrot's Beak Skarn (red)

\section{Figure 2 Ok Tedi pit 13D4 plan layout and geology (500 m grid)}



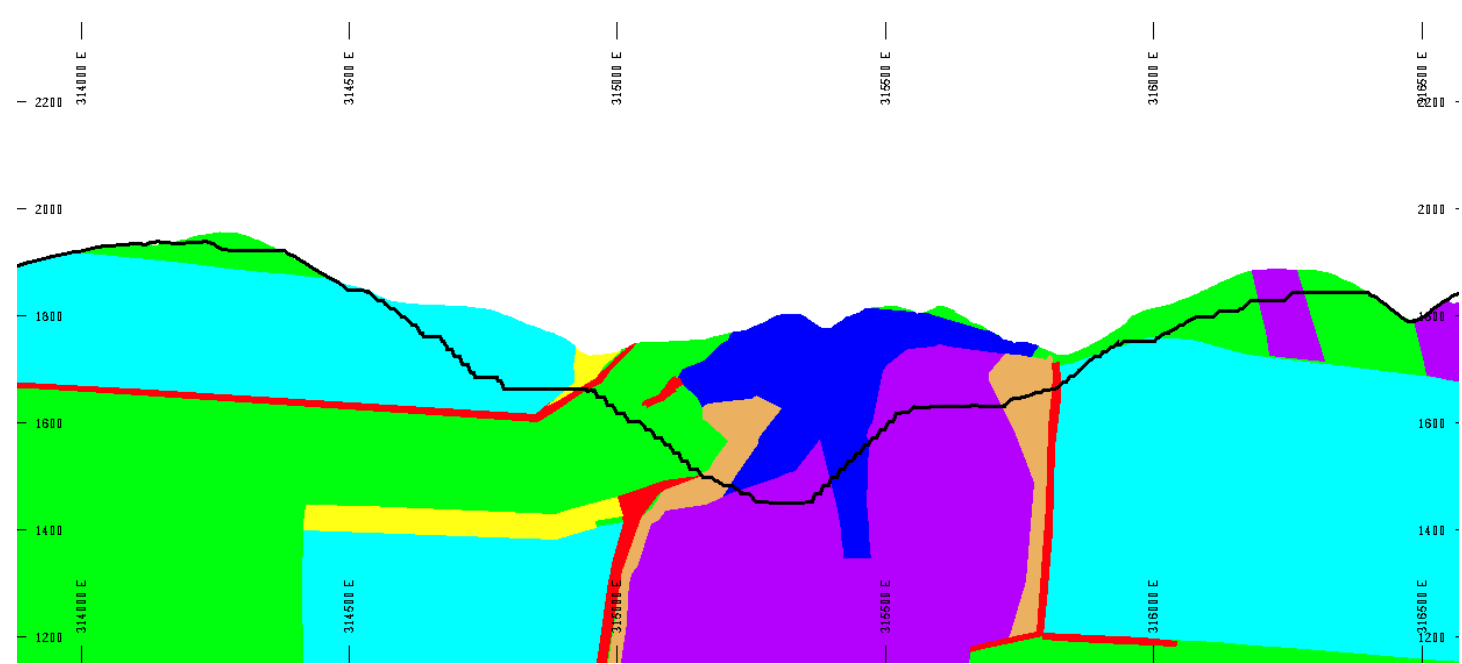

Figure 3 Ok Tedi pit: $423100 \mathrm{~N}$ east-west geological section (looking north)

The porphyry copper-gold deposit mined at Ok Tedi is part of the Fubilan Monzonite Porphyry which is part of the Ok Tedi Intrusive Complex. The age of the deposit is 1.1-1.3 million years. Skarn type mineralisation, locally with economic copper-gold concentration, is common. Emplacement of the monzodiorite was contemporaneous with contact metamorphism of the adjacent sedimentary host rocks, fracturing, thrust faulting, folding along the Ok Tedi Anticline and emplacement of dykes and sills.

\section{Mine structural geology}

In this paper, the term 'defect' broadly refers to any type of natural structural geological discontinuity in the rock mass; irrespective of its tectonic origin (i.e. joint, shear, fault, bedding, foliation or rock type contact). This approach has been used because geologists often find it difficult to distinguish between defect types when slope face mapping.

The Fubilan Monzonite Porphyry occupies the hinge zone of the Ok Tedi Anticline. The porphyry is typified by many fractures and small scale faults with surfaces usually coated by hydrothermal minerals. There are two major thrust zones; Taranaki and Parrot's Beak. The Taranaki Thrust Fault is $300 \mathrm{~m}$ stratigraphically above the Parrot's Beak Thrust Fault and dips at $8^{\circ}$ to the west and forms the contact between the Darai Limestone and the underlying Ieru Siltstone. The Parrot's Beak Thrust Fault dips at $20^{\circ}$ to the west. Movement along both thrusts continued during various spasms of intrusive activity. Thrusting occurred during and after copper and gold mineralising events. The thrust faults comprise highly fractured and altered fault gouge, pyrite and magnetite skarn lenses, brecciated monzodiorite and brecciated siltstone hornfels.

The base of the orebody is defined by the basal contact; previously known as the Deep Thrust. The contact is presently interpreted as a stratigraphic contact/unconformity rather than a thrust fault. There are numerous, largely sub-vertical, normal faults with slickensided clay gouge and sometimes hydrothermal alteration. At least two phases of faulting is interpreted, based on offsetting relationships.

There is a wide scatter of joint and other defect orientations across the mine workings; perhaps reflecting the development of both radial and tangential fracture sets around the intrusive, relative rotation of the thrust fault bounded major strata blocks and redistribution of orientations during up-doming/folding of the strata. Intrusion-associated clay alteration and geological veining/defect spacing are locally intense. Typical defect lengths and spacings are 3-20 $\mathrm{m}$ and $0.1-0.3 \mathrm{~m}$, respectively.

\section{Toppling failure geology}

The subject toppling failure is located at the southern end of the West Wall where mining activity has created a 'bullnose' shaped slope in plan view. Toppling instability now affects the slope face over an area of 300 by $200 \mathrm{~m}$ in horizontal and vertical directions. 

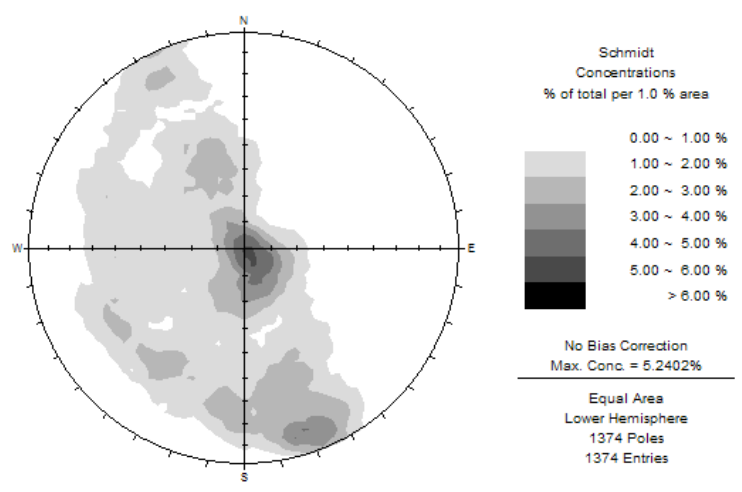

Paris Siltstone
SIROVISION Mapping Data
Defect Set Orientations
(Dip Direction/Dip Angle):
320/05
$340 / 80$
$160 / 30$
$155 / 75$

Lower hemisphere, equal area

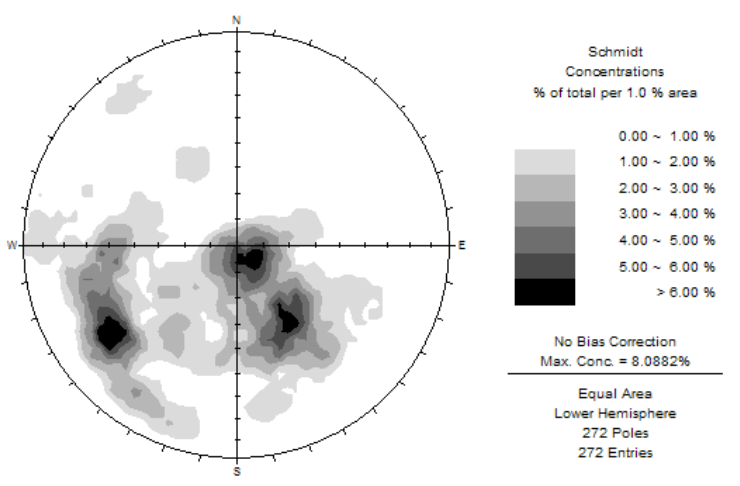

Paris Monzodiorite

SIROVISION Mapping Data

Defect Set Orientations

(Dip Direction/Dip Angle):

300/05

$325 / 35$

$055 / 60$

Lower hemisphere, equal area

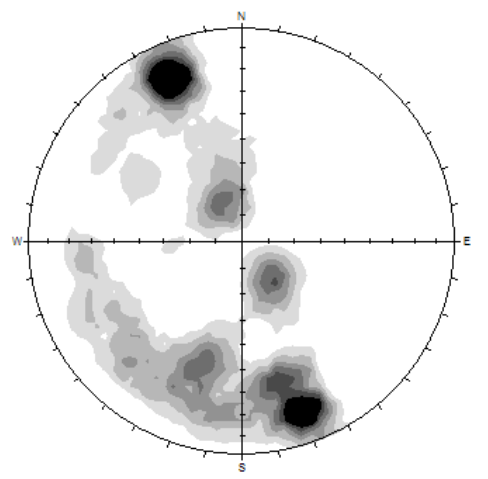

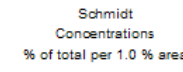

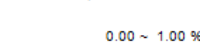

$1.00 \sim 2.00 \%$

$2.00 \sim 3.00 \%$

$3.00 \sim 4.00 \%$

$3.00 \sim 4.00 \%$

$4.00 \sim 5.00 \%$
$5.00 \sim 8.00 \%$

$>6.00 \%$

No Bias Correction
Max. Conc. $=9.1743 \%$

Equal Area

Lower Hemisphere
327 Poles
327 Eas

327 Entries
Paris Magnetite Skarn

SIROVISION Mapping Data

Defect Set Orientations

(Dip Direction/Dip Angle):

340/72

$155 / 70$

$320 / 20$

$155 / 18$

$020 / 50$

Lower hemisphere, equal area

\section{Figure 4 Stereographic projections for toppling failure area}

West Wall geology comprises Darai Limestone in the upper-third and Ieru Siltstone in lower two-thirds. The Taranaki Thrust zone (with skarn) defines the boundary between these two strata units.

At initiation in 2005, toppling was confined to one bench in the siltstone below the Taranaki Thrust Fault. Failure has now progressed down-slope to the slope toe and up-slope into limestone strata above this fault. Progression is on-going.

Eastern limit of toppling is coincident with the Monzodiorite and magnetite skarn contact, often comprising 5-15 m wide zone of faulted and intensively brecciated materials, on the lower slope.

The western limit is masked by remnants of an 'erodable' waste dump in the steeply incised Harvey Creek at the southern end of the pit (see the gully in the foreground and behind the bullnose in Figure 1). This creek, possibly coincident with a major steeply dipping normal fault, is the western limit of instability.

The structural pattern in both the siltstone and limestone is dominated by a pervasive set of defects that dip into the slope face and control the development of the toppling failure. These defects mostly dip at $45-85^{\circ}$ towards NNW (see defect traces on photo of slope face in Figures 11 and 12 and defect pole concentrations on stereoplots in Figure 4). Flattening and drag folding of these defects induced by tectonic displacements on 
faults are evident at some locations. A less well developed conjugate set of defects dip into the pit workings i.e. at $45-85^{\circ}$ towards SSE.

Two conjugate sets of sub-horizontal defect sets are widespread. The dominant set dips into the slope face i.e. at $5-15^{\circ}$ towards NNW (semi-parallel to thrust fault trend); the less common set dips into the pit; i.e. at $10-30^{\circ}$ towards SSE.

A less well defined set trends NNW-NW and dips into the pit direction; dipping at $60-70^{\circ}$ towards ENENE.

\section{Toppling failure mechanics}

The necessary rock mass conditions and basic mechanics of toppling failures are detailed in Hoek and Bray (1981) and Wyllie and Mah (2004).

Key conditions are:

- A well-developed structural fabric that dips steeply into the slope face.

- Geometry of rock blocks (plates, blocks or columns) isolated by defects with centres of gravity (i.e. W vector in Figure 5) located outside the blocks' respective bases.

- Other defect sets are present within the rock mass to define tops and bases and to provide side release in the third dimension for the respective rock blocks.

- When a key block located at the toe of the rock block network is sufficiently loosened or entirely dislodged to initiate the toppling failure process that progresses up-slope.

(a)

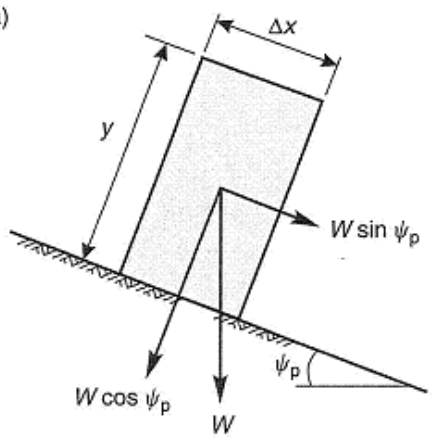

(b)

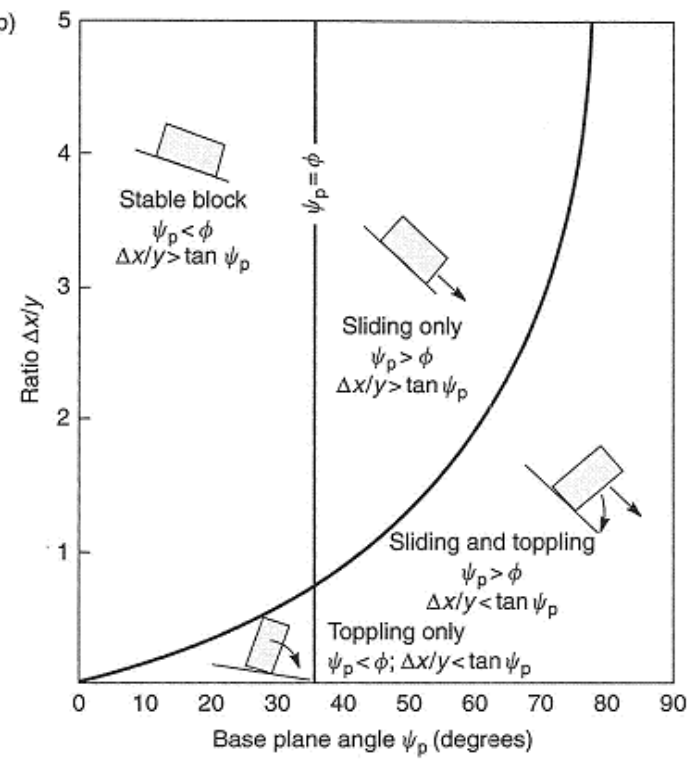

Figure 5 Geometrical conditions for rock block toppling failure (Wyllie and Mah, 2004)

Figure 5, reproduced from Wylie and Mah (2004), shows the relative displacements and progressive stages in the development of toppling failure where a single defect set dips steeply into the rock slope. In situations where sub-horizontal defects occur, the shown tensile bending failure of the rock mass columns or plates is unnecessary as the latter defects provide a base release mechanism for toppling instability.

\section{Predicted ground behaviour}

Toppling failure of some Ok Tedi mine slopes was anticipated on basis of kinematic stability analysis of the structural defect pattern during the 1997-2000 pit slope design optimisation study. Likely mechanics and 
potential extent of toppling failure were examined by means of FLAC and UDEC modelling (Itasca, 2004; Little et al., 1999-2000; Coulthard and Little, 1999).

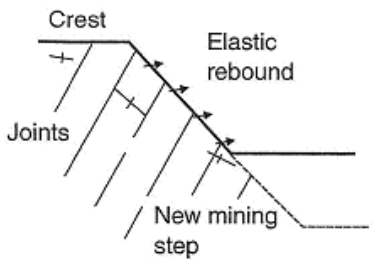

IV

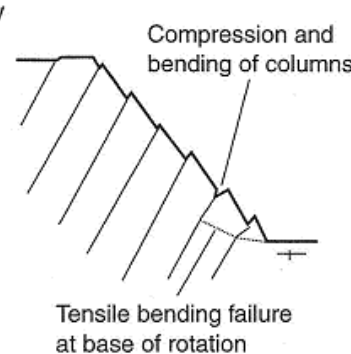

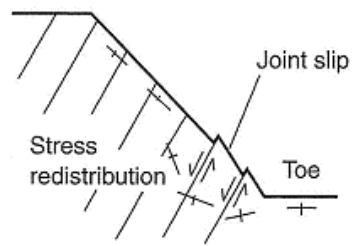

V

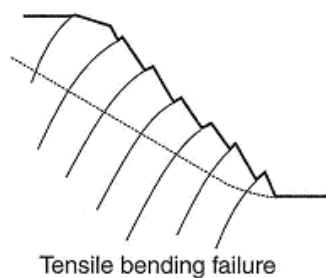

propagated to crest
III

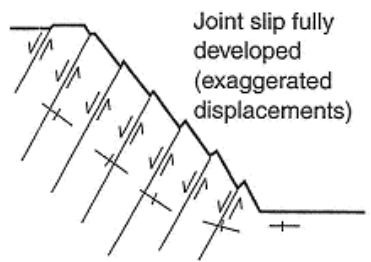

VI

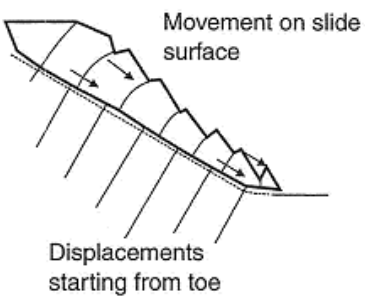

Figure 6 Toppling failure stages for slopes (Wyllie and Mah, 2004; after Sjoberg, 2000)

Further UDEC analyses by Coulthard $(2006,2007)$ have refined earlier predictions.

\subsection{UDEC modelling}

The 1997 UDEC modelled slope in Figure 7 was $700 \mathrm{~m}$ high. Subvertical defect spacings above and below the Taranaki Thrust Fault were $15 \mathrm{~m}$ and $30 \mathrm{~m}$ respectively; but this structural pattern did not continue into the strata below the Parrot's Beak Thrust Fault. The slope above the Taranaki Thrust was dewatered, but the watertable was only partially drawndown below this fault. A horizontal to vertical stress of $0.5-1.0$ was adopted.

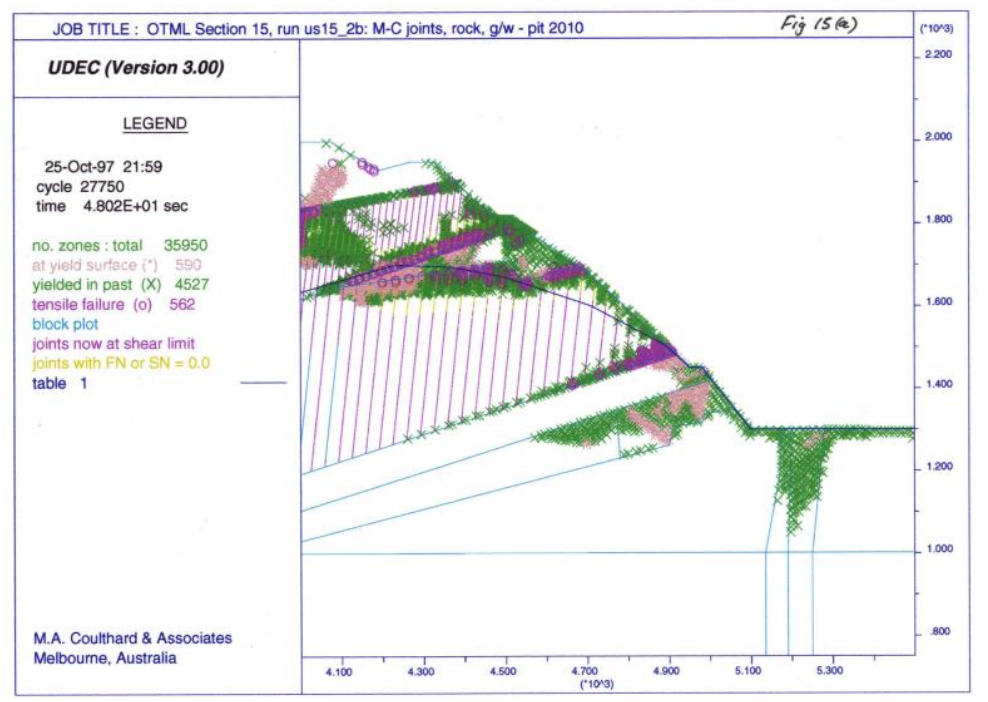

\section{Figure 71997 UDEC modelling suggesting toppling failure}

Whilst the 1997 UDEC modelling concluded that large scale toppling failure of the West Wall slope was possible, actual incidence of such failures on the slope excavated during the 1997-2000 study period was relatively minor. However, it is generally observed that many failures on high slopes display complex failure modes. Thus, a specific failure rarely involves a unique mode and the affected rock mass often exhibits a 
composite failure mode, locally ranging from circular slip to block or wedge sliding to toppling. Most instabilities at Ok Tedi Mine during 1997-2000 exhibited elements of both sliding and toppling; conclusive evidence for a unique toppling failure mechanism was interpretative and biased by the observer's perspective on which mode actually dominated the failure.

\subsection{UDEC modelling}

Following a late May 2006 initiation of a 3-4 m pulse of slope displacement, Dr Coulthard remodelled the situation. Figures 8 to 10 summarise the key UDEC modelling.

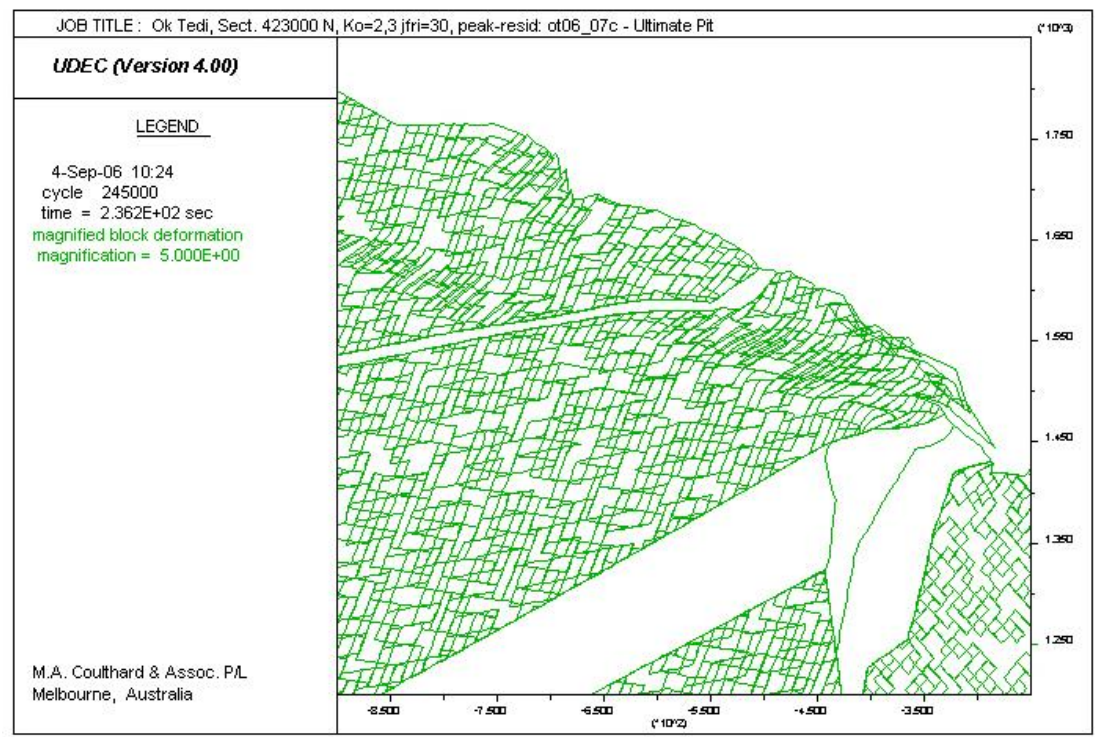

Taranaki Thrust: thin, clear/non-jointed, shallow dipping (to LHS) zone in mid slope; Parrot's Beak Thrust: thick, clear/non-jointed, dipping (to LHS) zone $150 \mathrm{~m}$ behind slope toe; Siltstone: jointed zone between Taranaki and Parrot's Beak Thrusts; Limestone: jointed zone above Taranaki Thrust; Endoskarn: clear zone below slope toe; Skarn: clear zone between Endoskarn and Parrot's Beak

\section{Figure 82006 UDEC modelling demonstrating toppling failure mechanism}

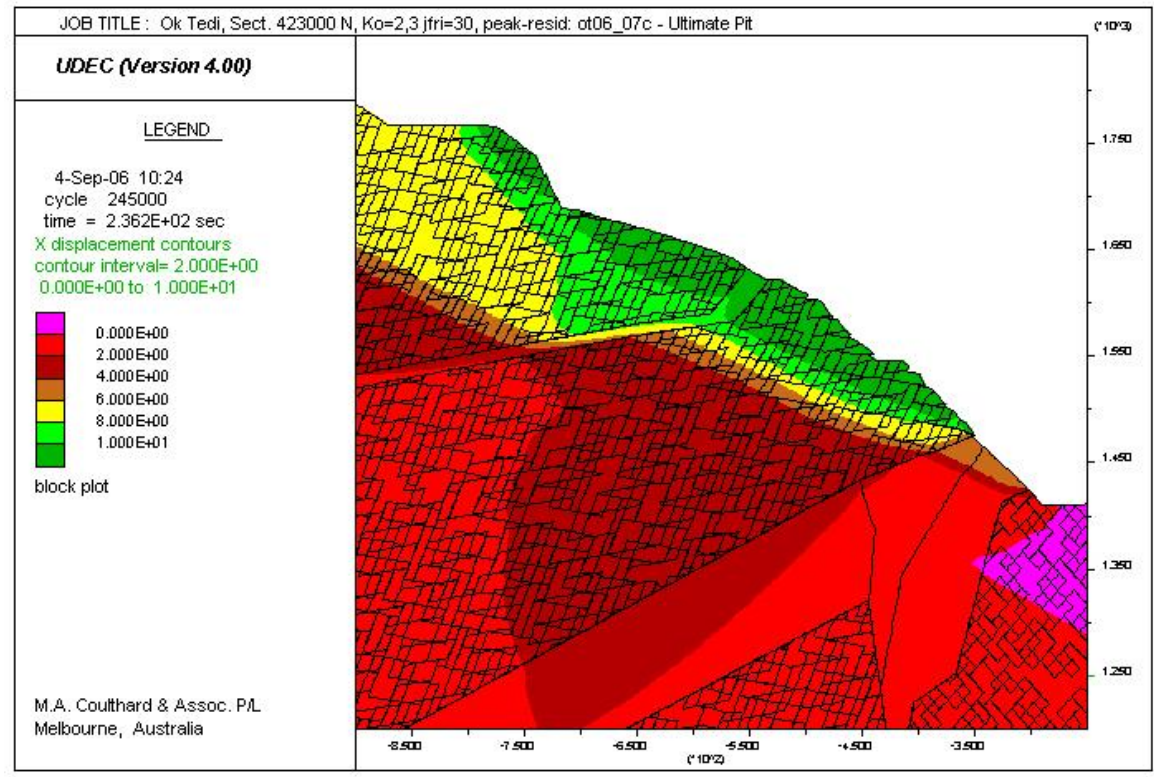

Figure 92006 UDEC modelling results: horizontal displacement contours for toppling failure 


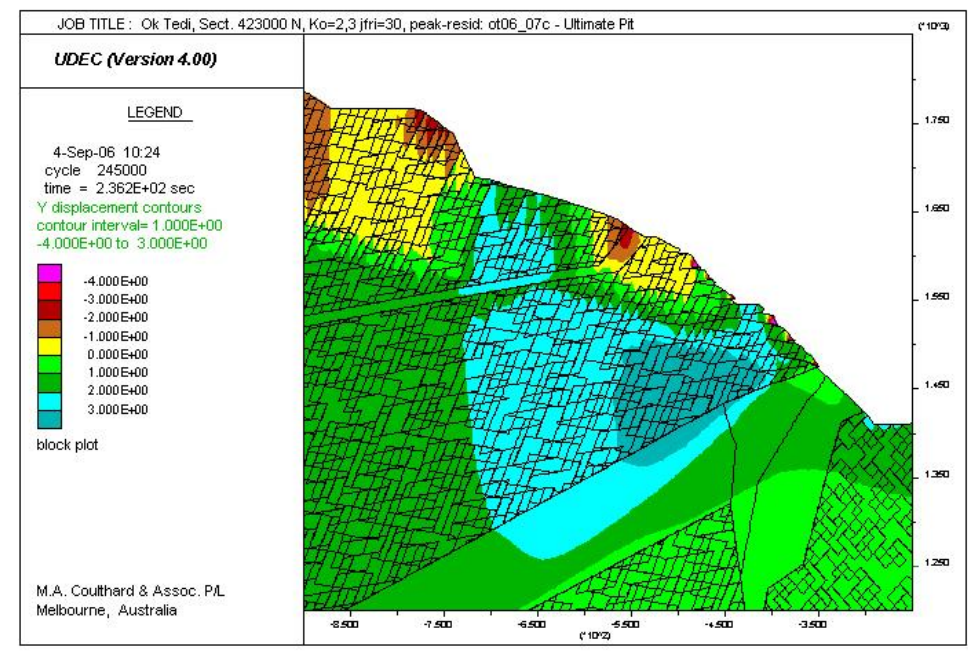

Figure 102006 UDEC modelling results: vertical displacement contours for toppling failure

Updated models included sub-vertical plus two sub-horizontal defect sets and horizontal to vertical stress ratios of three to one and two to one for the N-S and E-W directions, respectively. The groundwater drawdown profile was the same as the one adopted for the 1997 UDEC analyses.

The updated UDEC models predicted the following ground responses:

- Displacements on sub-vertical defects: the up-slope blocks to be displaced downwards with respect to the down-slope blocks, akin to Stage III mechanism shown in Figure 6.

- Displacements on sub-horizontal defects: the underlying slabs to slide out relative to the overlying slabs, creating ascending sub-horizontal steps on the slope face.

- Loosening of the rock mass between the Taranaki and Parrot's Beak Thrust Faults to depth of $40-80 \mathrm{~m}$ below the slope face; with the overall slope remaining stable.

- Cyclic displacement: the time-displacement plots showed step-ups, representing a rapid increase in ground displacement, as each bench lift was mined at the toe of the toppling failure slope, followed by plateaus representing abated displacement activity, with this cycle repeating when the next bench was mined.

- Cumulative displacements: $10 \mathrm{~m}$ and $3 \mathrm{~m}$ in horizontal and vertical directions, respectively; with a 3D cumulative displacement vector of $10-11 \mathrm{~m}$.

\section{Actual ground behaviour}

Geotechnical parameters for the bulk rock mass blocks and defects, groundwater conditions and in situ stresses dictate the response of UDEC models in terms of displacement magnitudes, extent of developed tensile zones and overall slope failures. However, sense of displacement on defects (i.e. failure mechanism) depends on defect orientations and spacings within the UDEC model. The geotechnical inputs to UDEC models reflected current understanding of conditions in the subject slope at Ok Tedi Mine. In the completed modelling, UDEC results were consistent with field observations, including sense of movement on defects, cyclic step-type displacements with mining of successive benches, total displacement magnitudes and lack of overall slope failure.

\subsection{Cumulative displacements}

Figures 13 and 14 summarise ground displacements which, till mid-April 2008, exceeded $8 \mathrm{~m}$. Further displacement is expected as the final bench lift is mined down. To date, the slope remains stable overall. 


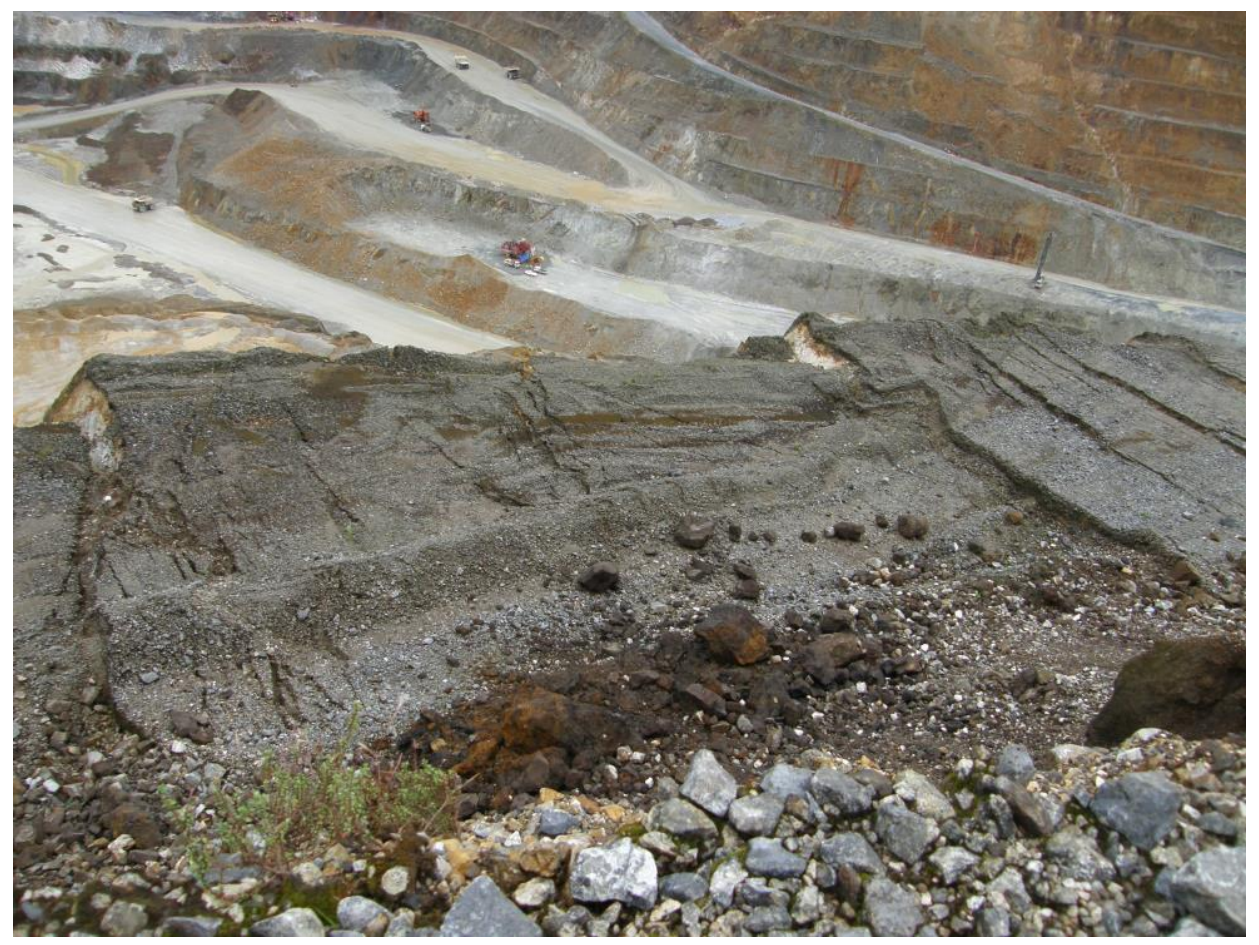

Figure $111.5 \mathrm{~m}$ step-up on defects: toppling failure direction is towards RHS (8 $\mathrm{m}$ wide bench)

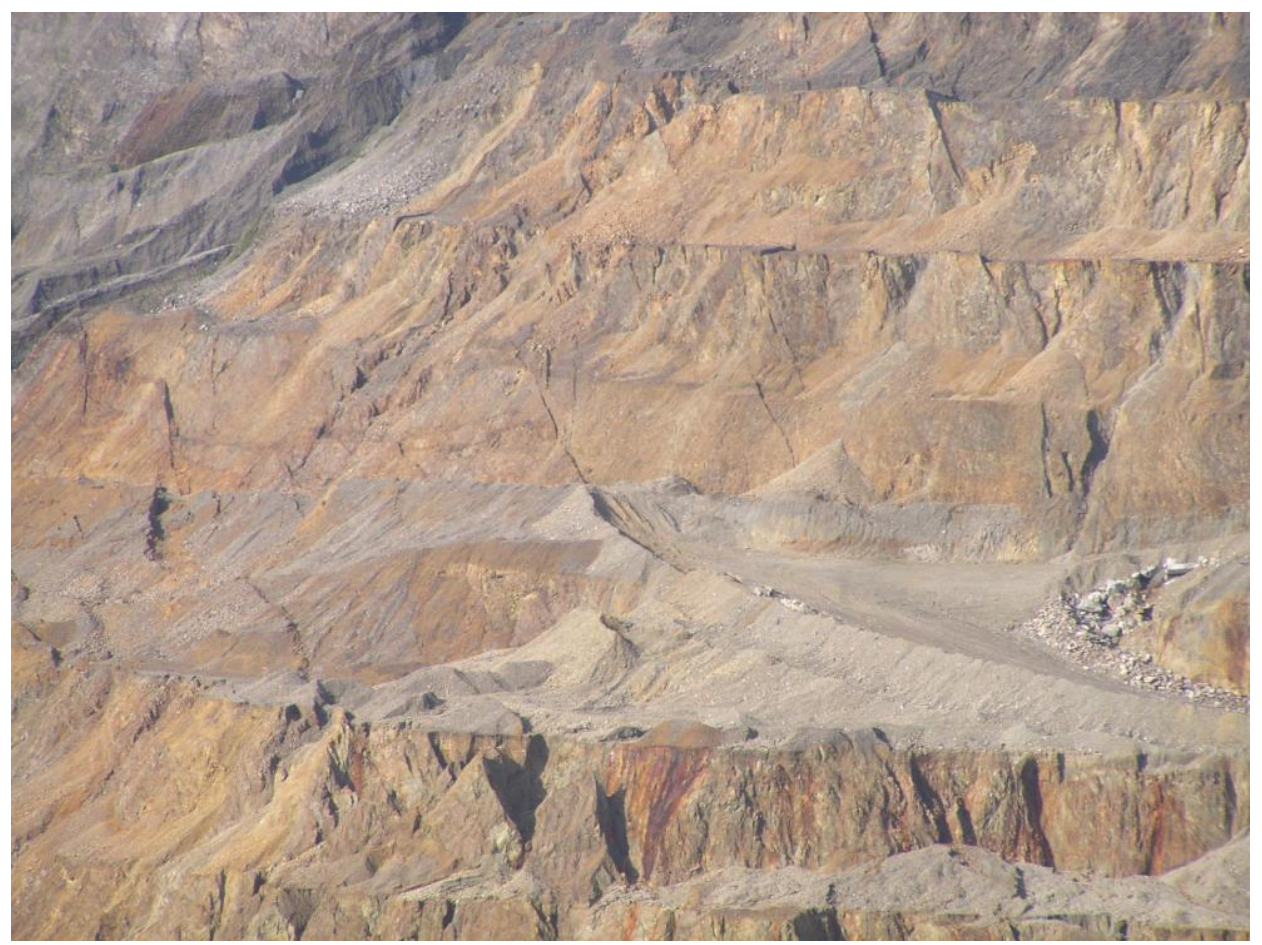

Figure 12 Side View of failure area, with toppling towards LHS (benches are $15 \mathrm{~m}$ high)

In June 2005, monitoring comprised tape measurement of distances between pegs installed on either side of individual cracks. In July-August 2005, Polchor surface wire extensometers were installed. In late November 2005, several survey prisms were added to the network; the number of prisms was doubled in June 2006. Six new wire extensometers were installed in July 2007. In parallel with this manual monitoring effort, the SoftRock Solutions' computerised EDM (electronic distance measuring) slope monitoring system was reviewed in February 2006, commissioned in April 2006 and installed in July 2006 but, due to persistent rain and cloud, only effectively trialled in September 2006. Manual and computerised EDM monitoring were 
undertaken in parallel during September and October 2006 to provide monitoring overlap, duplication and an emergency backup system and to enable comparison between the manual and computerised systems. For Ok Tedi, the ability of SoftRock Solutions' system to collect readings at night, when the probability of no fog is the highest during the foggy season, has been a big advantage that helped minimise disruptions to mining and haulage.

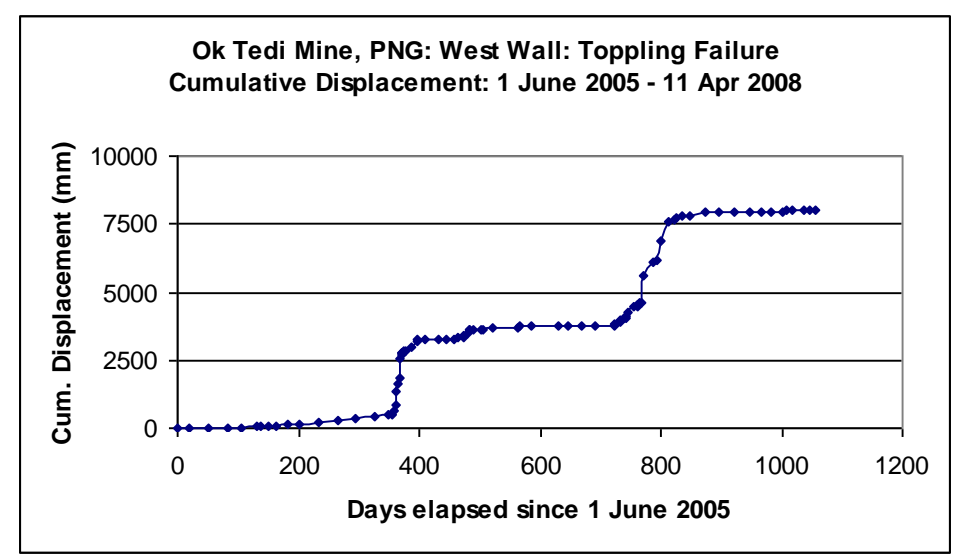

Surface extensometers (0-150 days); manual EDM (150-500 days); computerised EDM (500-1100 days)

Figure 13 Cumulative displacement

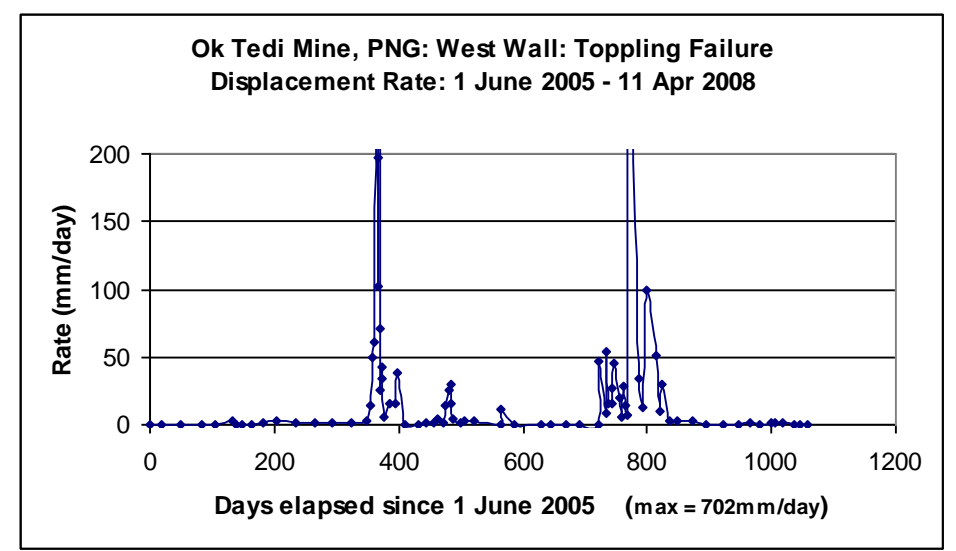

Figure 14 Displacement rates

Displacements averaged $1 \mathrm{~mm} /$ day from June 2005-May 2006 but displacements prior to monitoring are unknown.

In late May 2006, displacements accelerated rapidly during active mining along the slope toe. The maximum displacement rate exceeded $700 \mathrm{~mm} /$ day, but was generally less than $50 \mathrm{~mm} /$ day. Cumulative movement was 2.5-3 m within 5 weeks.

Displacements abated to 1-2 mm/day in July and August 2006; but another 0.3-0.4 m of cumulative movement occurred over two weeks in late September to early October 2006 when the next $15 \mathrm{~m}$ bench lift was partially mined.

Displacements averaged 1-2 mm/day from October 2006 to early May 2007. Another spasm with 4-4.5 m of cumulative displacement was triggered by blasting and mining activity along the slope toe in mid May 2007. This time, the maximum displacement rate reached $350 \mathrm{~mm} /$ day, but was generally less than $50 \mathrm{~mm} /$ day. Significant slope displacements persisted for three months.

Rates averaged $0.5-1 \mathrm{~mm} /$ day but with some periodic fluctuations from August 2007 to April 2008; the rate increased to 3-5 mm/day in late April 2008 after renewed mining activity along the slope toe. 


\subsection{Rainfall impact on displacement rates}

Figures 15 and 16 show that rainfall intensity and ground displacements were related (correlation coefficient of 0.82), especially at rainfall intensities in excess of $20 \mathrm{~mm} /$ day, whilst surface water runoff works were in progress. After the works were completed, correlation ceased even when rainfall intensity exceeded $100 \mathrm{~mm} /$ day.

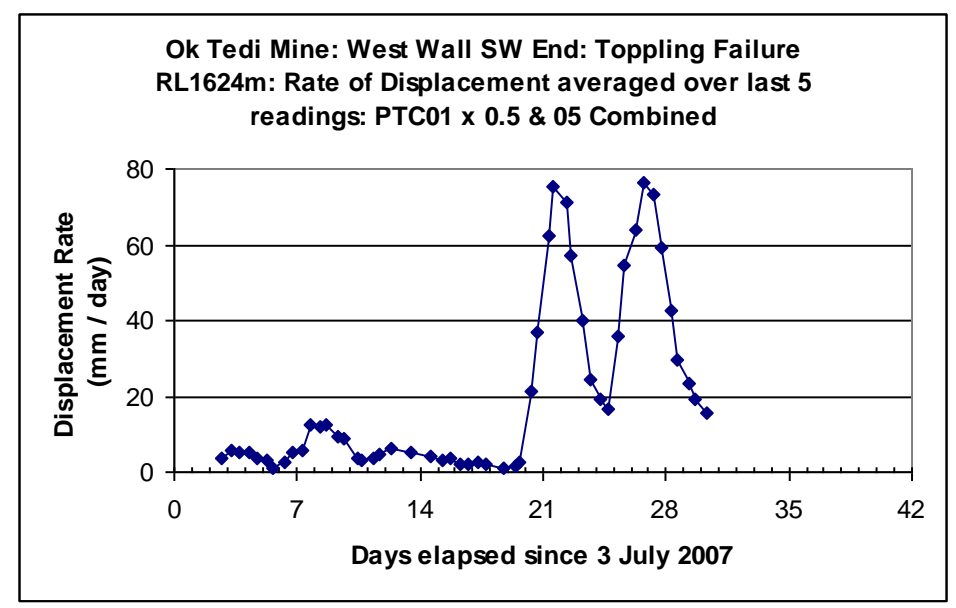

Figure 15 Displacement rates (surface extensometers: 3 July-3 August 2007)

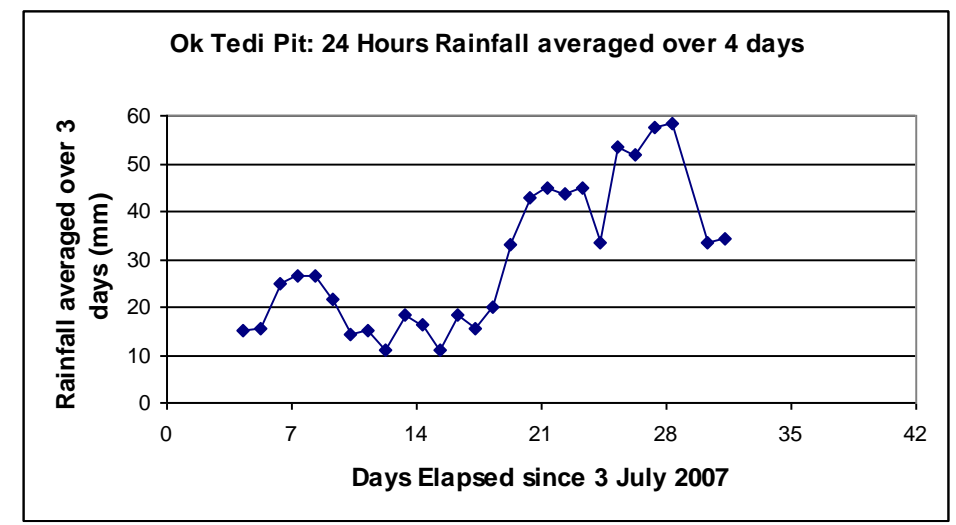

Figure 16 Pit rainfall intensities (3 July-3 August 2007)

\subsection{Blasting impacts on displacement rates}

Blasting and mining of ground along the toe of the subject slope markedly impact the toppling failure displacements.

Successive blasts along the slope toe (a) progressively loosen the already disturbed rock mass within the toppling failure and (b) reduce the modulus of the rock mass that buttresses the slope toe. The timedisplacement plot in Figure 13 suggests that, for the three bench lifts mined at Ok Tedi mine in May 2006, September 2006 and May 2007, toppling failure displacements in the subject slope increased to $15-30 \mathrm{~mm} /$ day immediately after blasting.

Subsequent mining of the blasted rock removed the slope toe restraint and further aggravated the stability situation. In all instances displacements rapidly, but briefly, accelerated to $100-700 \mathrm{~mm} /$ day before abating to around $30-50 \mathrm{~mm} /$ day whilst active mining was in progress. After mining, displacement often continued at $5-10 \mathrm{~mm} /$ day for several weeks before again abating to $0.5-1 \mathrm{~mm} /$ day.

\subsection{Monitoring limitations}

All slope stability monitoring methods have limitations. 
Where practical and safe regular walkover, geotechnical inspections of at-risk slope areas yielded first hand visual appreciation of instability situations. However, such inspections may fail to identify early stages of deep seated slope instabilities until the failures have progressed to a stage where surface cracks develop.

Early/preventative detection of ground displacements is best achieved by various EDM (electronic distance measuring) ground surface surveying methods (whether manual or computerised), manual and computerised GPS (geographic positioning system), computerised radar surface displacement monitoring methods and downhole instrumentation such as inclinometers, tilt meters and wire extensometers. Manual methods are labour intensive and provide field data at discrete points in time. Computerised methods provide real time slope stability monitoring but generate large volumes of data that require interpretative processing.

Irrespective of manual or computerised methods, the amassed data needs to be promptly processed, reviewed and interpreted, and the interpretation in terms of actual ground response must then be communicated to mine operations in order to provide a safer mine working environment. Unless this occurs the collected data dates rapidly and becomes only of historical interest and of little practical benefit to current mining decisions.

EDM/automatic total station (ATS) survey monitoring methods can only operate in favourable weather conditions. They cannot operate in rainy, cloudy, foggy or dusty conditions. Also, there is a limit to the distance over which the tools can effectively operate with acceptable accuracy.

Figure 17 shows that manual surveying results over distances of 2000-3000 m, even during a period of abated displacements, may vary from $+50--50 \mathrm{~mm} /$ day; this being the effective survey accuracy. The effective error for computerised ATS and manual GPS monitoring is about half the above and demonstrates the advantage of an instrument that is set-up once and never moved (except for maintenance and servicing). The accuracy limitation means that a rolling average of a few readings should be used during times of little or no movement.

The capability of the computerised slope monitoring radar has been developed only recently to a stage where it is now possible to read displacements over distances of $1800-2500 \mathrm{~m}$. The previous limiting distance was 850-900 m. This system will be trialled at Ok Tedi mine during July and August 2008.

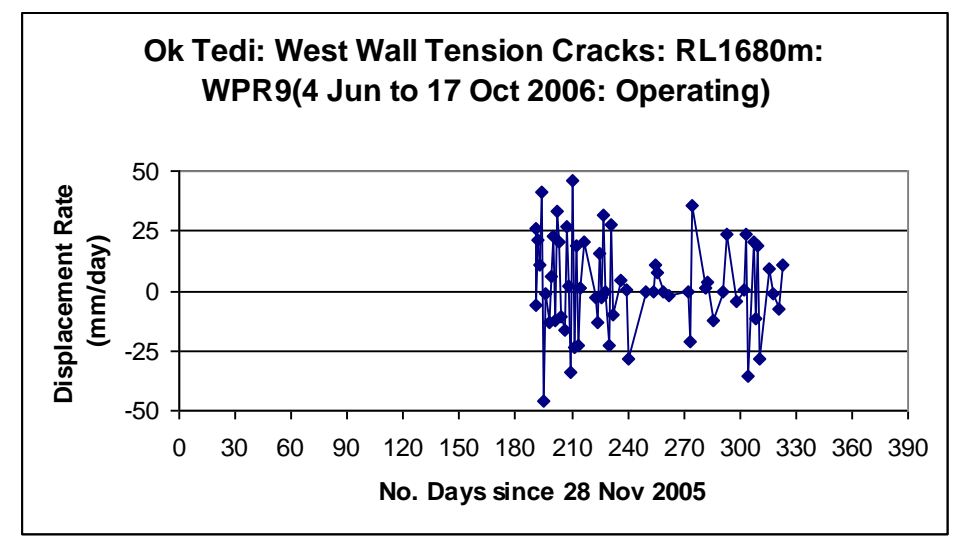

Figure 17 Probable survey accuracy (manual EDM): $\pm 25- \pm 50 \mathrm{~mm}$ over $2 \mathrm{~km}$

\section{Mining strategy}

Geotechnical inspections and ground control monitoring have guided continued mining activity beneath the toppling failure affected slope.

As far as practical, all surface water runoff has been channelled away from the cracked areas.

As each spasm of major displacements initiated, men and equipment have been promptly moved away from the toe of the affected slope and the area geotechnically re-inspected. As necessary, the at-risk pit area was shut down and/or barricaded off, often for several days or longer, until ground displacements abated to acceptable rates. 
With time, the monitoring network on the subject slope was extended, improved and computerised; the geotechnical understanding of the failure mechanism improved, and mining personnel refined their mining and blasting practices along the slope toe to minimise vibration. The latter was achieved by free-digging the rock mass where possible, reducing powder factors and blasting the ground in smaller mining blocks than was previously done.

There are now over 100 target prisms on the toppling failure slope. In favourable weather, each prism is being read three to five times each day by the computerised system and the collated data is interpreted daily.

A measure of stability monitoring duplication is being provided by daily geotechnical drive-over inspections and manually read extensometers.

To date, effective stability monitoring and improved mining practices have enabled the pit to be progressively deepened beneath the toppling failure slope area.

\section{Conclusions}

Toppling failures were anticipated during the 1997-2000 Ok Tedi risk-based slope design optimisation study on basis of the geological defect pattern and UDEC numerical modelling.

Toppling failure initiated on the mine's West Wall during 2005. Major displacements occurred in mid 2006 and 2007. Instability has been on-going as the pit has been deepened.

UDEC modelling in 2006-2007 predicted cumulative displacements of 10-11 m.

Predicted and actual ground behaviours have been similar. To date, cumulative movement in excess of eight metres has occurred.

Displacements rates have been cyclic. When the slope toe was being actively mined, displacements briefly exceeded $700 \mathrm{~mm} /$ day, but were generally less than $50 \mathrm{~mm} /$ day, and eventually abated to $0.5-1 \mathrm{~mm} /$ day.

Good correlations exist between rainfall, blasting and mining activity and toppling failure displacement rates.

Effective stability monitoring, diversion of surface water runoff and improved mining practices have enabled the pit to be safely advanced beneath the toppling failure slope area.

\section{Acknowledgements}

Dr M.A. Coulthard undertook all UDEC and FLAC numerical modelling cited in this technical paper. Regular stability inspections and monitoring in the subject toppling failure area were undertaken by various staff from the Geotechnical Engineering and Mine Surveying Sections at the Ok Tedi Mining Ltd; their dedication to these tasks, often under poor weather conditions, is greatly appreciated. The automated ATS slope monitoring system installed on mine slopes was developed by SoftRock Solutions Pty Ltd.

\section{References}

Coulthard, M.A. and Little, T.N. (1999) Modelling of stability of high westwall at Ok Tedi copper-gold mine. Proceedings of International Symposium on FLAC and Numerical Modelling in Geomechanics, Minneapolis, USA, C. Detournay and R. Hart (editors), Rotterdam: Balkema, pp. 39-46.

Coulthard, M.A. (2006) UDEC models for Section 423000N, Ok Tedi Mine, MA Coulthard Associates, Draft \#1 Report to OTML, Sept, 14 p.

Coulthard, M.A. (2007) UDEC stress analysis models of pit Section 423000N at Ok Tedi Mine, Draft Report to OTML, July, $37 \mathrm{p}$

Hoek, E. and Bray, J. (1981) Rock Slope Engineering, Third edition, Inst. Mining and Metallurgy, London, UK.

Itasca (2004) UDEC: Universal Distinct Element Code, Version 4.0, Itasca Consulting Group Inc., Minneapolis, USA.

Little, T.N., Cortes, J.P. and Baczynski, N.R. (1999-2000) Risk-based slope design optimisation study for the Ok Tedi copper-gold mine. Vols. 1-8, and Executive Summary, Ok Tedi Mining Limited, Mine Technical Services Department, Geotechnical Engineering Section.

Sjoberg, J. (2000) Failure mechanisms for high slopes in hard rock. Slope Stability in Surface. Society of Mining, Metallurgy and Exploration, Littleton, CO, pp. 71-80.

Wyllie, D.C. and Mah, C.W. (2004) Rock Slope Engineering: Civil and Mining (based on the third edition by E. Hoek and J. Bray). Fourth Edition, Spon Press, London and New York, 431 p. 
